\title{
Fire effects on the population structure of Zanthoxylum rhoifolium Lam (Rutaceae) in a Brazilian savanna
}

\author{
Silva, IA. *, Valenti, MW. and Silva-Matos, DM. \\ Departamento de Botânica, Universidade Federal de São Carlos - UFSCar, \\ Rod. Washington Luís, Km 235, CP 676, CEP 13565-905, São Carlos, SP, Brazil \\ *e-mail: igor6cordas@yahoo.com.br \\ Received January 14, 2008 - Accepted July 18, 2008 - Distributed August 31, 2008
}

(With 1 figure)

\begin{abstract}
Since cerrado fires may impede the growth of seedlings into trees, they may shape the population of woody species. In this study, we assessed the effects of a severe fire on the population structure and spatial distribution of Zanthoxylum rhoifolium, a widespread cerrado tree. We were interested to know the importance of the resprouting and sexual reproduction in regenerating the population. The study area had been for about six years protected from fire, before a severe fire at the end of the dry season in 2006. We sampled and measured all individuals of Z. rhoifolium found in 80 plots of $25 \mathrm{~m}^{2}$. We found 149 individuals before the fire and 112 after the fire, of which 77 were resprouts from burned seedlings and saplings. We did not find significant differences between the population structure before and after the fire. The spatial distribution of the population remained clumped after the fire. Thus, the Z. rhoifolium population was very resilient to a severe fire. We did not find any new seedlings. As a consequence, resprouting seems to be more important than sexual reproduction in promptly regenerating the Z. rhoifolium populations.
\end{abstract}

Keywords: cerrado, resilience, resprouting, sexual reproduction, spatial distribution.

\section{Efeitos do fogo na estrutura da população de Zanthoxylum rhoifolium Lam (Rutaceae) em uma savana brasileira}

\begin{abstract}
Resumo
Uma vez que as queimadas no cerrado podem impedir o crescimento de plântulas, elas podem moldar a população de espécies arbóreas. Neste estudo, avaliamos os efeitos de uma queimada severa na estrutura e na distribuição espacial da população de Zanthoxylum rhoifolium, uma espécie de árvore comum no cerrado. O objetivo era saber a importância relativa do rebrotamento e da reprodução sexuada na regeneração da população. A área de estudo, há aproximadamente seis anos sem queimar, sofreu uma queimada severa no final da estação seca de 2006. Amostramos todos os indivíduos de Z. rhoifolium encontrados em 80 parcelas de $25 \mathrm{~m}^{2}$. Encontramos 149 indivíduos antes do fogo e 112 depois dele, dos quais 77 eram rebrotas de plântulas e jovens queimados. Não encontramos diferenças significativas entre a estrutura da população antes e após o fogo. A distribuição espacial da população permaneceu agregada após a queimada. Portanto, a população de Z. rhoifolium foi resiliente ao fogo. Não foi encontrada nenhuma nova plântula. Consequentemente, o rebrotamento parece ser mais importante que a reprodução sexuada na regeneração imediata das populações de Z. rhoifolium.
\end{abstract}

Palavras-chave: cerrado, distribuição espacial, rebrotamento, reprodução sexual, resiliência.

\section{Introduction}

In South America, the largest savanna region is the Brazilian cerrado (Gottsberger and Silberbauer-Gottsberger, 2006). Like its overseas savanna counterparts, cerrado vegetation is resilient to fire, with woody populations having well-developed capabilities of regenerating, either vegetatively or by seed (Coutinho, 1990; Gottsberger and Silberbauer-Gottsberger, 2006). In addition, most tree species present strong suberization of stems and/or subterranean meristems, which pro-

tect them from high temperatures. (Miranda et al., 1993; Moreira, 2000; Gottsberger and Silberbauer-Gottsberger, 2006). Despite these adaptations, fire may kill seedlings and impede their growth into trees (Raw and Hay, 1985; Hoffmann, 1996). Consequently, it may shape the population structure of woody species (Hoffmann, 1998).

The spatial distribution of the individuals of a plant population is related to the spatial pattern of recruitment and the modification of this pattern by mortality factors, 
such as fire, which differ in intensity from place to place (Hutchinson, 1997). The pattern of spatial distribution of species may be random, uniform, or clumped. Random distribution is rare in plant populations (Hutchinson, 1997), however it may occur when the environment does not set the limit on the establishment and survival of the individuals (Hay et al., 2000). The uniform pattern is also uncommon and may arise when the intraspecific plant competition for space or resources sets the limit on the co-occurrence of the individuals (Hay et al., 2000). Conversely, the clumped pattern is frequent and widespread in cerrado tree populations (Oliveira et al., 1989; San Jose et al., 1991; Hay et al., 2000). It is attributed either to patchiness of favorable soil conditions or to dispersal limitation (Condit et al., 2000). In savannas, the clumped pattern of plants could also be related to resprouting stimulated by constant environmental constraints, such as fire (San Jose et al., 1991). Thus, fire may increase the clumping of some woody cerrado populations (San Jose et al., 1991).

Little is known about how fire affects the establishment of trees in cerrados. Hoffmann (1998) showed that fire tends to increase the importance of vegetative reproduction in comparison to sexual reproduction. Nevertheless, this still remains controversial, mainly because the strategies of only a few species have been studied until now. Oliveira and Silva (1993) demonstrated that seeds of Kielmeyera ssp. germinated readily and had high survival rate in the cerrado after a burning. Likewise, García-Núñez et al. (2001), in an annually burned Venezuelan savanna, found a high proportion of germinated seeds of Byrsonima crassifolia and Palicourea rigida, species that also occur in cerrado. Therefore, studies on the effects of fire on the populational biology of other cerrado species are necessary to understand the general cerrado resilience to fire.

We investigated the effects of a severe anthropogenic fire on the population structure of Zanthoxylum rhoifolium Lam, a common tree in cerrado sites. We compared the density and the distribution of individuals in size classes before and after fire. We also evaluated the strategy for regenerating the population, by comparing the number of seedlings to resprouts.

\section{Material and Methods}

\subsection{Ecological data}

We carried out this study in a cerrado site of about 125 ha, classified as cerrado sensu stricto (a woodland) according to Coutinho (1990), in the Federal University of São Carlos, in the city of São Carlos, São Paulo state, southeastern Brazil (21 ${ }^{\circ} 58^{\prime} 22^{\circ} 00^{\prime} \mathrm{S}$ and $\left.47^{\circ} 51^{\prime}-47^{\circ} 52^{\prime} \mathrm{W}\right)$. Regional climate is warm temperate with wet summer and dry winter (Cwa; Köppen, 1948). Annual rainfall and mean annual temperature lie around $1340 \mathrm{~mm}$ and $22{ }^{\circ} \mathrm{C}$, respectively. The soil is dystrophic on a flat topography and the water-table is reached at $10 \mathrm{~m}$ below the soil surface (Damascos et al., 2005). The area is crossed by firebreaks to prevent the spread of fire. The firebreaks are roads of about four meters wide without vegetation. In August 2006, an accidental anthropogenic fire burned the whole western portion of the cerrado site. The area had been unburned for approximately six years and much dry biomass had accumulated during those years. As a result, this anthropogenic fire was quite severe, burning the canopy of some trees and killing some adults.

Zanthoxylum rhoifolium Lam (Rutaceae) is a deciduous tree species that grows up to $12 \mathrm{~m}$ tall. It is a common and widespread distributed tree in cerrado and forest areas in virtually all central and south Brazil (Das Chagas e Silva and Soares-Silva, 2000; Oliveira-Filho et al., 2001; Neto et al., 2002; Bridgewater et al., 2004). The species is not shade-tolerant and is more frequently found in gaps and borders of forests. The fruit is a spherical capsule, black when ripe, about $5 \mathrm{~mm}$ in length and $5 \mathrm{~mm}$ in width. Seeds are small, about $3 \mathrm{~mm}$ long and $3 \mathrm{~mm}$ wide, with no aril, and with a hard coat (Silva and Paoli, 2000).

We systematically placed four transects from a firebreak at $20 \mathrm{~m}$ from each other. In each transect, we established successive 20 plots of $25 \mathrm{~m}^{2}$. In November 2005, we counted and analysed all individuals of $Z$. rhoifolium found in these 80 plots. We marked and measured the height and diameter at the soil level of all individuals sampled. In November 2006, in the middle of the rainy season and three months after the fire, we resurveyed the four transects and recounted and analysed all individuals again, measuring of their height and diameter at soil level. We also counted the new seedlings and resprouts. When resprouts were not evident, we dug around the individuals, generally small ones, searching for a remaining burned stem or root.

\subsection{Data analysis}

We tested whether the distribution of the number individuals per plot before and after the fire fit a normal distribution (D'Agostino test). Then, we compared the density of the population before the fire to the density after the fire, with the nonparametric Wilcoxon paired-sampled test. This test is recommended when samples are dependent (Zar, 1999). The data collected in 2006 were strongly associated to data collected in 2005 because we resampled the individuals at the same plots.

Then, we tested whether the distribution of the height and diameter values before and after the fire fit a normal distribution (D'Agostino test). We tested the correlation between height and diameter of the individuals sampled with the Spearman's rank correlation (rs). Since we found a positive correlation between these two variables, we assessed the structure of the Z. rhoifolium population only with height measures. We compared the median height of the Z. rhoifolium population per transects before fire to the median height after fire, with the Wilcoxon paired sample test. 
We analysed the distribution of individuals in height classes and the spatial distribution with three set of data: 1) the individuals sampled before fire; 2) the individuals sampled after fire; and 3) the individuals sampled after fire without resprouts. We first grouped the individuals of these data sets in height classes. We established the number and the intervals of classes according to the Sturges's (1926) rules. We computed the number of classes $(\mathrm{K})$ as follows:

$$
\mathrm{K}=1+3.222 \log \mathrm{N}
$$

where $\mathrm{N}$ is the $\mathrm{n}$ number of individuals sampled. We computed the interval of the classes $(\mathrm{H})$ as follows:

$\mathrm{H}=\mathrm{A} / \mathrm{K}$

where $\mathrm{A}$ is the amplitude of data (the highest minus the lowest value of height and diameter). Then, we made pairwise comparisons of the three distributions of frequency in height classes each other by a chi-square test (homogeneity analysis).

To assess the spatial pattern of the population distribution before fire, after fire, and after fire without resprouts, we compared the observed distribution of frequency of individuals in the plots to that expected by the Poisson distribution (goodness of fit analysis). When the observed distribution did not differ from the Poisson distribution, the spatial distribution of the population is random. When the observed distributions were different, we estimated the Morisita's (1962) dispersion coefficient $\left(\mathrm{I}_{\mathrm{d}}\right)$ as follows:

$I_{d}=n\left[\frac{\sum x_{i}^{2}-\sum x_{i}}{\left(\sum x_{i}\right)^{2}-\sum x_{i}}\right]$

where $n$ is the number of plots sampled and $x_{i}$, the number of individuals in each plot. An $\mathrm{I}_{\mathrm{d}}$ higher than 1 indicates a clumped spatial distribution of population, whereas an $I_{d}$ lower than 1 , a uniform spatial distribution (Morisita, 1962). Finally, we compared the distribution of frequency of individuals in the plots before fire to the distribution after fire (homogeneity analysis).

We conducted the statistical analyses with the BioEstat 3.0 computer package (Ayres et al., 2003).

\section{Results}

We found 149 individuals of Z. rhoifolium before the fire and 112 after the fire, of which 77 were direct resprouts from burnt saplings. We did not observe any new root sucker resprouts (a new stem originating from a root bud at some distance from the parent stem). The distribution of number of individuals per plot did not fit a normal distribution $(\mathrm{D}=0.194, \mathrm{P}<0.01$ and $\mathrm{D}=0.223$, $\mathrm{P}<0.01$ before and after the fire respectively). The density was not affected by the fire $(\mathrm{T}=701.0, \mathrm{P}=0.898)$. The mean densities before and after the fire were respectively $1.87 \pm 3.53$ and $1.53 \pm 2.40$ individuals per plot (mean and standard deviations). We did not find any new seedlings after the fire.

The distribution of height and diameter values did not fit a normal distribution $(\mathrm{D}=0.216, \mathrm{P}<0.01$ and $\mathrm{D}=0.210, \mathrm{P}<0.01$ for height and diameter before the fire, and $\mathrm{D}=0.210, \mathrm{P}<0.01$ and $\mathrm{D}=0.204, \mathrm{P}<0.01$ for height and diameter after the fire respectively). The height of the individuals was positively correlated with the diameter $\left(\mathrm{r}_{\mathrm{s}}=0.829, \mathrm{t}=18.033, \mathrm{P}<0.001\right.$ for individuals before the fire and $r_{s}=0.713, t=10.534, P<0.001$ for individuals after the fire). The median heights of the Z. rhoifolium population before and after the fire were respectively $20.0 \pm 0.16 \mathrm{~cm}$ and $10.0 \pm 0.08 \mathrm{~cm}$ (median and quartile). The median height after the fire was significantly lower than before the fire $(Z=-1.826$, $\mathrm{P}=0.049$ ).

We grouped the individuals in eight height classes with an interval of $60 \mathrm{~cm}$ (Figure 1). We did not find significant differences between the distributions of individuals in height classes before and after the fire (Figure $1 ; \mathrm{x}^{2}=17.41, \mathrm{P}=0.201$ ). However, after the fire, the individuals found in the first height class were either resprouts from burned saplings or unburned already marked saplings. As a consequence, when we compared the distributions of individuals before and after the fire to the distribution after the fire without those resprouts, we found a significant decrease in the number of individuals in the first height class (Figure $1 ; \mathrm{x}^{2}=34.89, \mathrm{P}<0.001$ and $\mathrm{x}^{2}=23.09, \mathrm{P}=0.002$ respectively). Therefore, fire affected mainly groups of small sized plants.

The Z. rhoifolium population before and after fire presented a clumped spatial pattern $\left(x^{2}=27.02\right.$, d.f. $=5$, $\mathrm{P}<0.005, \mathrm{I}_{\mathrm{d}}=3.99$ and $\mathrm{x}^{2}=20.30$, d.f. $=5, \mathrm{P}<0.005$, $I_{d}=2.81$ respectively). The clumping of the population after fire was not significantly different from the population before fire $\left(\mathrm{x}^{2}=5.68\right.$, d.f. $\left.=5, \mathrm{P}=0.338\right)$. However, the spatial distribution of the population after fire without resprouts was indistinguishable from random $\left(x^{2}=3.16\right.$, d.f. $=5, P=0.206)$. Thus, resprouting is quite important in promptly regenerating the $Z$. rhoifolium population.

\section{Discussion}

Since cerrado fires may impede the growth of seedlings into trees (Raw and Hay, 1985; Hoffmann 1996, Hoffmann and Moreira, 2002), they may shape the population structure and spatial distribution of woody species. In this study, we assessed the effects of a severe fire on the population structure and spatial distribution of Z. rhoifolium, a widespread cerrado tree. We found that, in general, fire did not modify the population structure of Z. rhoifolium and that resprouting was more important than sexual reproduction in regenerating promptly the population after fire.

Fire is expected to remove mainly the seedlings and saplings and to increase the median height of the population as a result (Hoffmann and Solbrig, 2003). For example, Raw and Hay (1985) demonstrated that 
Before fire

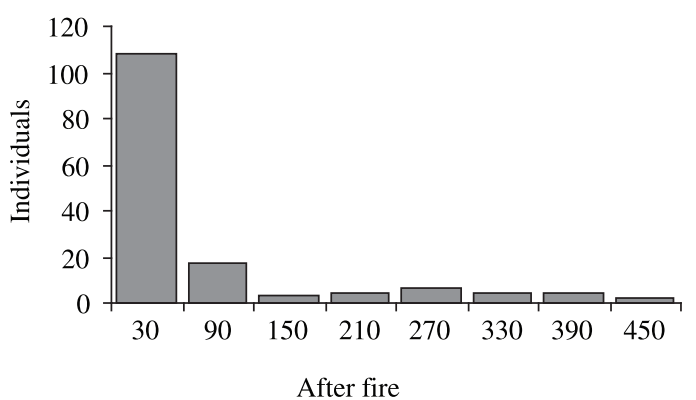

After fire

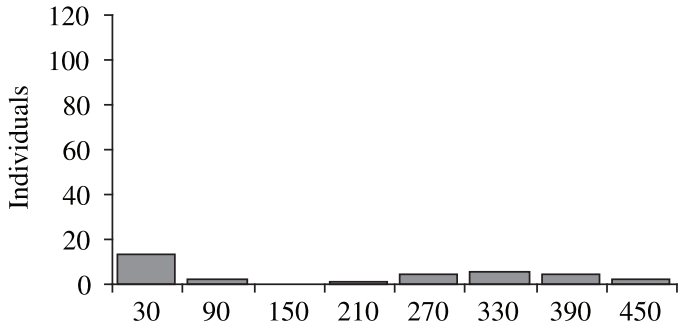

Height classes $(\mathrm{cm})$

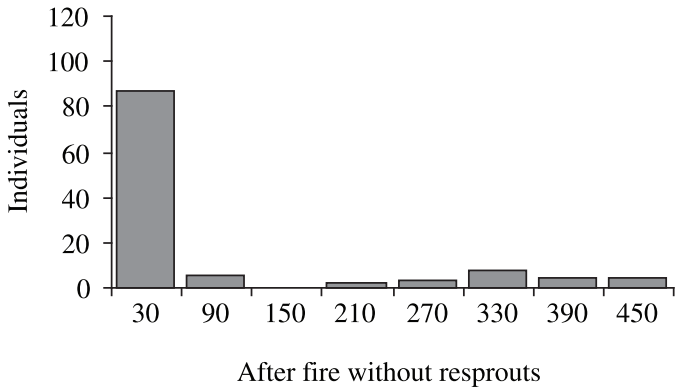

After fire without resprouts

Figure 1. Distribution of Zanthoxylum rhoifolium Lam individuals in height classes $(60 \mathrm{~cm})$ in a southeastern cerrado site (São Carlos, SP, Brazil) before and after a severe anthropogenic fire in August 2006. Values on the abscissa are means of the height classes.

Simarouba amara, a common cerrado tree, requires at least 10 years of growth before developing morphological immunity to fire. Consequently, juveniles are more susceptible to fire than adults. On the contrary, our analysis showed both a great number of resprouts from seedlings and a reduction of the median height of the Z. rhoifolium population after fire. This reduction may have occurred due to the overall great number of individuals resprouting, which did not have enough time to attain the immunity size before fire. Hence, our results support the well-corroborated hypothesis that fires open cerrado physiognomy (Coutinho, 1990), reducing the height of woody species (Moreira, 2000).

A common phenomenon to fire-induced plant communities is the flush of germination and growth of seedlings after fire (for chaparral see Tyler 1995). For some cerrado tree species, sexual reproduction after fire plays a major role in regenerating the populations (Oliveira and Silva, 1993; García-Núñez et al., 2001). However, we did not observe any seedling after fire, but many resprouts from saplings. Xavier et al. (2007) accompanied the germination from the seed bank in our study area and did not observe any seedlings of $Z$. rhoifolium. Thus, resprouting seems to be more important than sexual reproduction in promptly regenerating the Z. rhoiflium populations after fire. Studies should be performed to evaluate if seedling establishment may improve by the second year following the fire event, as occurred in some cerrado species (Hoffmann, 1996).
In general, cerrado species present a high capacity to resprout because of greater investment in total below-ground biomass (Hoffmann and Moreira, 2002). Hoffmann and Franco (2003), for example, found that the root-shoot ratio of savanna species averaged $82 \%$ greater than forest species. Thus, the great number of saplings resprouting after fire indicates that $Z$. rhoifolium accumulates enough underground reserves to resist fire early in the ontogenetic development. Although fire affects mainly early age groups (Raw and Hay, 1985), this adaptation suggests that general size structure of Z. rhoifolium is only slightly affected as most of the saplings do not die, but resprout after fire.

The spatial distribution of $Z$. rhoifolium individuals remained clumped after the fire because of resprouting. The clumped spatial pattern has already been observed in other species of cerrado (Oliveira et al., 1989) and savannas (Greig-Smith, 1991; San Jose et al., 1991). In some other savanna species, severe fires removed mainly the seedlings, promoting a decrease in the clumping of the populations (Greig-Smith, 1991). However, our results indicate that a single severe fire did not change the clumping of the $Z$. rhoifolium population, even though it removed some saplings and adults. In savannas, clumping has been associated with the distribution of suitable soil characteristics in patches and fire occurrence (Greig-Smith, 1991). Fire, in this case, may promote resprouting of many root suckers (San Jose et al., 1991). On the contrary, we did not observe any root 
sucker. All resprouts were direct resprouts from saplings. Thus, the clumped spatial pattern found after fire was a direct consequence of the clumped spatial pattern before fire rather than an effect of the resprouting. This pattern may be related to the distribution of suitable soil characteristics.

In conclusion, Z. rhoifolium is very resilient to fire and resprouting seems to be the more important process in regenerating promptly the population after fire. As sexual reproduction is fundamental in regenerating the population of other species, both ecological strategies may be important in cerrado. Future studies should be performed to evaluate the relative importance of each strategy for the cerrado community.

Acknowledgements - We are grateful to Capes and CNPq, for the scholarship granted to the first author and to M.V. Cianciaruso, for help in the field.

\section{References}

AYRES, M., AYRES Jr., M., AYRES, DL. and SANTOS, AS., 2003. BioEstat 3.0: aplicações estatísticas nas áreas das ciências biológicas e médicas. Belém: Sociedade Civil de Mamirauá. $291 \mathrm{p}$.

BRIDGEWATER, S., RATTER, JA. and RIBEIRO, FR., 2004. Biogeographic patterns, b-diversity and dominance in the cerrado biome of Brazil. Biodiversity and Conservation, vol. 13, no. 12 , p. 2295-2318.

CONDIT, R.,ASHTON, PS., BAKER, P., BUNYAVEJCHEWIN, S., GUNATILLEKE, S., GUNATILLEKE, N., HUBBEL, SP., FOSTER, RB., ITOH, A., LaFRANKIE, JV., LEE, HS., LOSOS, E., MANOKARAN, N., SUKUMAR, R. and YAMAKURA, T., 2000. Spatial patterns in the distribution of tropical tree species. Science, vol. 288, no. 5470, p. 1414-1418.

COUTINHO, LM., 1990. Fire in the ecology of the Brazilian cerrado. In Goldammer, JG. (Ed.). Fire in the tropical biota. Berlin: Springer. p. 81-103.

DAMASCOS, MA., PRADO, CHBA. and RONQUIM, CC., 2005. Bud composition, branching patterns and leaf phenology in cerrado woody species. Annals of Botany, vol. 96, no. 6, p. $1075-1084$.

Das CHAGAS e SILVA, F. and SOARES-SILVA, LH., 2000. Arboreal flora of the Godoy forest state park, Londrina, PR, Brazil. Edinburgh Journal of Botany, vol. 57, no. 1, p. 107-120.

GARCÍA-NÚÑEZ, C., AZÓCAR, A. and SILVA JF., 2001. Seed production and soil seed bank in three evergreen woody species from a neotropical savanna. Journal of Tropical Ecology, vol. 17 , no. 4, p. 563-576.

GOTTSBERGER, G. and SILBERBAUER-GOTTSBERGER, I., 2006. Life in the cerrado: a South American tropical seasonal vegetation. Vol. 1. Origin, structure, dynamics and plant use. Ulm: Reta Verlag. 277 p.

GRIEG-SMITH, P., 1991. Pattern in a derived savanna in Nigeria. Journal of Tropical Ecology, vol. 7, no. 4, p. 491-502.

HAY, JD., BIZERRIL, MX., CALOURO, AC., COSTA, EMN., FERREIRA, AA., GASTAL, MLA., GOES Jr., CD., MANZAN, DJ., MARTINS, CR., MONTEIRO, JMG., OLIVEIRA, SA., RODRIGUES, MCM., SEYFFARTH, JAS. and WALTER,
BMT., 2000. Comparação do padrão de distribuição espacial em escalas diferentes de espécies nativas do cerrado em Brasília, DF. Revista Brasileira de Botânica, vol. 23, no. 3, p. 341-347.

HOFFMANN, WA., 1996. The effects of cover and fire on seedling establishment in a neotropical savanna. Journal of Ecology, vol. 84, no. 3 p. 383-393.

HOFFMANN, WA., 1998. Post-burn reproduction of woody plants in a neotropical savanna: the relative importance of sexual and vegetative reproduction. Journal of Applied Ecology, vol. 35 , no. 3, p. 422-433.

HOFFMANN, WA. and MOREIRA, AG., 2002. The role of fire in population dynamics of woody plants. In OLIVEIRA, PS. and MARQUIS, RJ. (Eds.). The cerrados of Brazil: ecology and natural history of a Neotropical Savanna. New York: Columbia University Press. p. 159-177.

HOFFMANN, WA. and FRANCO, AC., 2003. Comparative growth analysis of tropical forest and savanna woody plants using phylogenetically-independent contrasts. Journal of Ecology, vol. 91, no. 3, p. 475-484.

HOFFMANN, WA. and SOLBRIG, OT., 2003. The role of topkill in the differential response of savanna woody species to fire. Forest ecology and management, vol. 180, no. 1, p. 273-286.

HUTCHINSON, MJ., 1997. The structure of plant populations. In CRAWLEY MJ. (Ed.). Plant ecology. Oxford: Blakwell Science. p. 325-358.

KÖPPEN, W., 1948. Climatología. Ciudad del México: Fondo de Cultura Económica. 466 p.

MIRANDA, AC., MIRANDA, HS., DIAS, IO. and DIAS, BF., 1993. Soil and air temperatures during prescribed Cerrado fires in central Brazil. Journal of Tropical Ecology, vol. 9, no. 3, p. 313-320.

MIRANDA, HS., BUSTAMANTE, MC. and MIRANDA, AC., 2002. The fire factor. In OLIVEIRA, PS. and MARQUIS, RJ. (Eds.). The Cerrados of Brazil: ecology and natural history of a Neotropical Savanna. New York: Columbia University Press. p. 51-68.

MOREIRA, AG., 2000. Effects of fire protection on savanna structure in Central Brazil. Journal of Biogeography, vol. 27, no. 4, p. 1021-1029.

MORISITA, M, 1962. Is index a measure of dispersion of individuals? Research on Population Ecology, vol. 1, no. 1, p. 1-7.

OLIVEIRA-FILHO, AT., CURI, N., VILELA, EA. and CARVALHO, DA., 2001. Variation in tree community composition and structure with changes in soil properties within a fragment of semideciduos forest in south-eastern Brazil. Edinburgh Journal of Botany, vol. 58, no. 1, p.139-158.

OLIVEIRA, PE., RIBEIRO, JF. and GONZALES, MI., 1989. Estrutura e distribuição espacial de uma população de Kielmeyera coriaceae Mart. de cerrados de Brasília. Revista Brasileira de Botânica, vol. 12, no. 1, p. 39-47.

OLIVEIRA, PE. and SILVA, JCS., 1993. Reproductive biology of two species of Kielmeyera (Guttiferae) in the cerrados of Central Brazil. Journal of Tropical Ecology, vol. 9, no. 1, p. 67-79.

RAW, A. and HAY, J., 1985. Fire and other factors affecting a population of Simarouba amara in cerradão near Brasília, Brazil. Revista Brasileira de Botânica., vol. 8, no. 1, p. 101-107. 
RONDON NETO, RM., WATZLAWICK, LF., CALDEIRA, MVW. and SCHOENINGER, ER., 2002, Análise florística e estrutural de um fragmento de floresta ombrófila mista montana, situado em Criúva, RS - Brasil. Ciência Florestal, vol. 12, no. 1, p. 29-37.

SAN JOSE, JJ., FARINAS, MR. and ROSALES, J., 1991. Spatial patterns of trees and structuring factors in a Trachypogon savanna of the Orinoco llanos. Biotropica, vol. 23, no. 2, p. 114-123.

SILVA, LL. and PAOLI, AAS., 2000. Caracterização morfoanatômica da semente de Zanthoxylum rhoifolium Lam.- Rutaceae. Revista Brasileira de Sementes, vol. 22, no. 2, p. 250-256.
STURGES, HA., 1926. The choice of class intervals. Journal of the American Statistical Association, vol. 21, no.153, p. 65-66.

TYLER, CM., 1995. Factors contributing to postfire seedling establishment in chaparral: direct and indirect effects of fire. Journal of Ecology, vol. 83, no. 6, p. 1009-1020.

XAVIER, RO., SILVA MATOS, DM. and DODONOV, P., 2007. Composição do banco de sementes numa área de cerrado queimada em São Carlos, SP, Brasil. In Anais do 58 Congresso Nacional de Botânica, outubro, dia 28. São Paulo: Sociedade Brasileira de Botânica.

ZAR, JH., 1999. Biostatistical analysis. New Jersey: Prentice Hall. 663 p. 